\title{
TINGKAT AGRESIVITAS ATLET PENCAK SILAT SUMATERA UTARA MENGIKUTI PEKAN OLAHRAGA WILAYAH IX DI BANGKA BELITUNG
}

\author{
Oleh \\ Indah Verawati ${ }^{1}$, Ratna Manda Sari ${ }^{1}$ \\ ${ }^{1}$ Fakultas Ilmu Keolahragaan, Universitas Negeri Medan \\ Email: ratnamandasari@gmail.com
}

\begin{abstract}
Abstrak
Penelitian ini bertujuan untuk mengetahui tingkat agresivitas atlet pencak silat Sumatera Utara mengikuti Pekan Olahraga Wilayah IX di Bangka Belitung 2015. Metode penelitian ini menggunakan metode deskriptif yaitu dengan teknik pengumpulan data menggunakan tes penyebaran angket dalam mengumpulkan data penelitian. Adapun jumlah subjek penelitian 27 atlet pencak silat. Instrumen yang digunakan untuk mengetahui data tingkat agresivitas atlet pencak silat Sumatera Utara mengikuti Pekan Olahraga Wilayah IX di Bangka Belitung adalah angket yang sebelum dilakukan penelitian angket terlebih dahulu diuji cobakan,untuk melihat validitas dan reliabilitas angket. Adapun hasil validitas angket motivasi berprestasi berada pada $\left(\mathbf{r}_{\text {hitung }}\right)=-0,059-0,897$ dengan $\mathbf{r}_{\text {tabel }}=$ 0,444. Nilai reliabilitas angket tingkat agresivitas sebesar $\mathbf{r}$ hitung $=0,9873$ dengan $\mathbf{r}_{\text {tabel }}=\mathbf{0 , 4 4 4}$, maka secara kolektif angket tersebut dinyatakan reliabel. Dari 40 butir angket yang diuji cobakan, menghasilkan 23 butir pernyataan yang valid dan 17 pernyataan yang tidak valid. Hasil analisis data menunjukkan bahwa tingkat agresivitas atlet pencak silat Sumatera Utara mengikuti Pekan Olahraga Wilayah IX di Bangka Belitung berdasarkan indikator diperoleh hasil sebagai berikut: 1) rasa marah $62.03 \%$ dengan kategori baik, 2) emosi $69.44 \%$ dengan kategori baik, 3) frustasi $64.81 \%$ dengan kategori baik, 4) curiga $80 \%$ dengan kategori baik sekali, 5) cemburu $77.27 \%$ dengan kategoribaik, 6) merasa diperlakukan tidak adil $63.76 \%$ dengan kategori baik, 7) bersilang pendapat 66.81\% dengan kategori baik, 8) membentak $74.56 \%$ dengan kategori baik, 9) berdebat $82.91 \%$ dengan kategori baik sekali, 10) mengancam 82.91\% dengan kategori baik sekali. Dapat disimpulkan bahwa motivasi berprestasi dengan nilai persentase jumlah keseluruhan adalah $\mathbf{7 3 . 1 3 \%}$ termasuk dalam kategori baik.
\end{abstract}

Kata Kunci: Agresivitas, Atlet Pencak Silat.

\section{A. PENDAHULUAN}

Pencak silat merupakan pertandingan olahraga kompetitif, ketika berhadapan langsung dengan lawan, mereka bukan sekedar melakukan kegiatan olahraga, tetapi lebih dari itu, terlibat kontak langsung untuk menyerang, seperti hanya ketika berhadapan dengan musuh yang harus dikalahkan.Pencak silat menampilkan 2 (dua) pesilat dari kubu-kubu berbeda yang saling berhadapan dengan menggunakan unsur pembelaan dan serangan yaitu menangkis/mengelak/menyerang pada sasaran dan 
menjatuhkan lawan.Menggunakan teknik dan taktik bertanding, ketahanan stamina dan semangat juang, menggunakan kaidah pola langkah yang memanfaatkan kekayaan teknik jurus untuk mendapatkan nilai terbanyak dalam waktu yang ditentukan.

Prestasi dalam pertandingan pencak silat merupakan suatu tujuan. Penampilan seorang atlet berhubungan dari berbagai faktor, disamping jenis olahraga, maka tingkat pertandingan, kompetisi atau kejuaraan juga berpengaruh terhadap para atlet. Prestasi yang baik merupakan target yang selalu didambakan seorang atlet. Prestasi yang diraih atlet yang terkait dengan mental atau psikologis. Proses menuju prestasi puncak dalam olahraga seorang atlet tidak hanya memiliki fisik yang kuat tetapi harus tahu siapa dirinya, apa kehendaknya, dan kapan dia harus melangkah.

Data prestasi atlet pencak silat Sumatera Utara yaitu pada Pekan Olahraga Wilayah VII tahun 2007 atlet pencak silat Sumatera Utara memperoleh 2 medali emas yaitu Apriansyah kelas E putra dan Jumidar Oktina Kelas E putri, dan 4 medali perungggu yaitu Emis Nursalim kelas C putra, Dameita Pinem kelas G putra, Kiki Syahputri kelas A putri dan Dinda Ayu Permatasari kelas D putri. Pada PON ke XVII/ Kaltim tahun 2008 memperoleh 1 perak yaitu Febriana E Lubis dan Nurjannah ganda putri. Selanjutnya pada Pekan Olahraga Wilayah VIII di Kepulauan Riau tahun 2011 atlet pencak silat Sumatera Utara meningkatkan prestasi dengan 4 emas yaitu: Dinda Ayu Permatasi kelas D putri, Ario wulan kelas H putra, Andi Zulkarnaen kelas G putra, dan Zumidar Oktina kelas E Putri, 2 perak yaitu Afriansyah kelas E putra, dan M.Ihwa, Zulfan, dan M. Saleh beregu putra dan 2 perunggu yaitu, Pedomanta Keliat kelas F putra dan Heri Kiswanto tunggal putra . Dan menurunnya pada PON XVIII/ Riau tahun 2012 atlet pencak silat hanya memperoleh 1 medali emas Afriansyah kelas E putra dan 1 medali perunggu Zumidar Oktina kelas E putri.

Hasil perolehan medali Pekan Olahraga Wilayah VIII dengan PON XVIII cabang olahraga pencak silat Sumatera Utara dapat diklasifikasi sebagai berikut:

Tabel 1 .

Perolehan Medali PORWIL VIII 2011 dan PON XVIII 2012

\begin{tabular}{lcccc}
\hline \multicolumn{2}{c}{ Kejuaraan } & \multicolumn{3}{c}{ Medali } \\
\cline { 2 - 5 } & Emas & Perak & Perunggu \\
\hline $\begin{array}{l}\text { Pekan Olahraga } \\
\text { (PORWIL) VIII/ Kepri 2011 }\end{array}$ & 4 & 2 & 1 \\
\hline $\begin{array}{l}\text { Pekan Olahraga Nasional } \\
\text { (PON) XVIII 2012 }\end{array}$ & 1 & - & 1 \\
\hline
\end{tabular}


Dari data diatas menurunnya prestasi atlet pencak silat Sumatera Utara dari Pekan Olahraga Wilayah VIII di Kepri 2011 ke Pekan Olahraga Nasional XVIII di Riau dan salah satu faktor prestasi atlet pencak silat Sumatera Utara menurun adalah agresivitas. Karena dalam olahraga body contact ini memungkinkan atlet bersinggungan secara langsung sehingga akan mudah memancing munculnya perasaan emosi dan agresivitas dalam cabang ini sangat mempengaruhi Prestasi Atlet Pencak Silat Sumatera Utara.

Pada Pekan Olahraga Wilayah ke IX di Bangka Belitung tahun 2015 ini, atlet pencak silat Sumut yang berjumlah 27 orang yang berasal dari beberapa kabupaten, saat ini sedang dalam masa Training Center (TC) di Lubuk Pakam Kabupaten Deli Serdang. Atlet pencak silat Sumatera Utara mempunyai harapan yang sangat luar biasa, yaitu lolos kualifikasi menuju Pekan Olahraga Nasional (PON) ke XIX di Bandung dengan prestasi terbaik mendapatkan medali emas di Pekan Olahraga IX Bangka Belitung. Kondisi atlet pencak silat Sumatera Utara saat ini sedang mempersiapkan diri menjalani program latihan yang diberikan pelatih berupa latihan fisik, teknik, dan taktik, selain itu diperlukan juga kesiapan psikologis untuk dapat mencapai kemampuan permainan terbaik. Baik buruknya kemampuan seorang atlet di lapangan akan mempengaruhi psikologi atlet khususnya seperti sifat agresif seorang atlet. Dan tingkat agresivitas setiap atlet pencak silat sumatera utara berbeda- beda. Hal itu dapat dilihat pada saat atlet latihan sparing fathner (berkelahi berpasangan) dan disinilah dapat diketahui Atlet mana yang memiliki agresivitas lebih tinggi.

Keberhasilan atlet dipengaruhi oleh sejumlah faktor yang saling mendukung antara faktor yang satu dengan lainnya. Faktor tersebut berasal dari dalam maupundari luar atlet itu sendiri yang meliputi faktor fisik, psikis, teknik, taktik, pelatih,sarana dan prasarana latihan, latihan, sosial, dan sebagainya. Menurut Alderman dalam Sudibyo Seyobroto (1993:16) menyatakan bahwa penampilan atlet dapatditinjau dari empat dimensi yaitu :1). Dimensi kesegaran jasmani meliputi antara laindaya tahan, daya ledak, kekuatan, kecepatan, kelentukan, kelincahan, reaksi,keseimbangan, ketepatan, dan sebagainya. 2). Dimensi keterampilan meliputi antara lain: kinestetika, kecakapan berolahraga tertentu, koordinasi gerak, dan sebagainya. 3). Dimensi bakat pembawaan fisik meliputi antara lain: keaadan fisik, tinggi badan, berat badan, bentuk badan, dan sebagainya. 4). Dimensi psikologi meliputi: motivasi, percaya diri, agresivitas, disiplin, 
kecemasan, intelegensi, keberanian, bakat, kecerdasan, emosi, perhatian, kemauan, dan sebagainya.

Menurut Berkowitz (Sukadiyanto 2005: 377), agresif merupakan suatu bentuk perilaku yang mempunyai niat tertentu untuk melukai secara fisik atau psikis pada diri orang lain "Agresif secara fisik meliputi kekerasan yang dilakukan secara fisik, seperti memukul, menampar, menendang dan lain sebagainya. Selain itu agresif secara verbal adalah penggunaan kata-kata kasar seperti bego, tolol. Selain bentuk agresif tersebut, ada faktor yang mempengaruhinya dalam perbuatan agresif diantaranya faktor belajar, faktor imitasi,dan faktor penguatan.

Agresivitas bagi seorang atlet pencak silat itu sangat diperlukan. Saleh (1983:1) menjelaskan bahwa cabang-cabang olahraga dimana terdapat sentuhan fisik langsung memerlukan keberanian menyerang. Sifat agresif mutlak diperlukan oleh setiap atlet olahraga beladiri. Setyobroto (1989:57) menjelaskan: Pemain-pemain yang agresif sangat diperlukan untuk dapat memenangkan pertandingan, seperti dalam sepak bola, tinju dsb., tetapi sifat dan sikap-sikap agresif apabila tidak terkendali dapat menjurus pada tindakan-tindakan berbahaya, melukai lawan, melanggar peraturan dan mengabaikan sportivitas.

\section{B. METODE PENELITIAN}

Penelitian ini dilaksanakan di Lubuk Pakam, Kabupaten Deli Serdang, dimulai bulan September 2015- Januari 2016. Subyek penelitian yang dipergunakan dalam penelitian ini adalah atlet pencak silat Sumatera Utara yang berjumlah 27 orang. Metode penelitian yang digunakan adalah metode deskriptif dengan cara menyebarkan angket kepada atlet pencak silat sumut.

Uji Validitas Tes

Pengujian di sini menggunakan rumus korelasi product moment (Arikunto, 2005 : 171).

$$
\begin{gathered}
r_{x y}-\ldots \frac{n \sum x y-\left(\sum x\right)\left(\sum y\right)}{\sqrt{\left\{n \sum x^{2}-\left(\sum x\right)^{2}\right\}\left(n \sum y^{2}-\left(n \sum y\right)^{2}\right\}-}} \\
\text { Apabilar } r_{\text {hitung }}>r_{\text {tabel }} \text { pada taraf signifikan 95\% dan } \alpha=5 \% \text { maka dapat }
\end{gathered}
$$
disimpulkan bahwa tes dinyatakan valid. Sebaliknya jikar $r_{\text {hitung }}<r_{\text {tabel }}$, maka tes dinyatakan tidak valid. 


\section{Uji Reliabilitas Tes}

Menurut Arikunto (2005 : 180), rumus untuk menghitung reliabilitas angket adalah:

$$
r_{I I}=\left(\frac{n}{n-1}\right)\left(1-\frac{\sum \alpha i^{2}}{\alpha i^{2}}\right)
$$

Bila $r_{\text {hitung }}>r_{\text {tabel }}$ untuk taraf signifikan $\alpha=0,5$ maka dapat disimpulkan bahwa angket yang digunakan sudah valid/ reliabel. Reliabilitas angket yang diperoleh dari hasil perhitungan dikonsultasikan dengan tabel product moment yaitu:

Tabel 2.

Interpretasi Nilai $r$

\begin{tabular}{|c|c|}
\hline Besar NIlai r & Interprestasi \\
\hline Angka 0,800 sampai dengan 1,000 & Tinggi \\
\hline Angka 0,600 sampai dengan 0,800 & Cukup \\
\hline Angka 0,400 sampai dengan 0,600 & Agak Rendah \\
\hline Angka 0,200 sampai dengan 0,400 & Rendah \\
\hline Angka 0,000 sampai dengan 0,200 & Sangat Rendah atau Tidak Korelasi \\
\hline
\end{tabular}

Setiap pilihan jawaban di atas mempunyai skor yang diurutkan dari yang tertinggi sampai yang terendah yaitu:

Tabel 3.

Skor Penilaian

\begin{tabular}{cc|cc}
\hline \multicolumn{2}{c}{ Option Angket Favourable } & \multicolumn{2}{c}{ Option Angket Unfavourable } \\
\hline Sangat Sesuai & $\mathbf{4}$ & Sangat Sesuai & $\mathbf{1}$ \\
\hline Sesuai & $\mathbf{3}$ & Sesuai & $\mathbf{2}$ \\
\hline Tidak Sesuai & $\mathbf{2}$ & Tidak Sesuai & $\mathbf{3}$ \\
\hline Sangat Tidak Sesuai & $\mathbf{1}$ & Sangat Tidak Sesuai & $\mathbf{4}$ \\
\hline
\end{tabular}

Data yang diperoleh dan dianalisis dengan persentase yaitu :

$$
P=\frac{F}{N} \times 100 \% \text { (Rosmala Dewi, 200:114) }
$$

Setelah dilakukan analisis data, kemudian hasil tersebut diklasifikasikan sebagai berikut :

Tabel 4.

Klasifikasi Penilaian

\begin{tabular}{ccc}
\hline No & Persentase Norma & Norma \\
\hline 1 & $80-100 \%$ & Baik Sekali \\
\hline 2 & $60-79 \%$ & Baik \\
\hline 3 & $40-59 \%$ & Sedang \\
\hline 4 & $20-39 \%$ & Kurang \\
\hline 5 & $50-19 \%$ & Kurang Sekali \\
\hline
\end{tabular}




\section{HASIL PENELITIAN DAN PEMBÄASAN}

\section{HASIL PENELITIAN}

Hasil berikut ini hasil validitas angket dukungan sosial orang tua.

a. Indikator rasa marah, diperoleh sebagai berikut: yang menjawab pada nomor item positif SS $=7$ dengan skor $28, \mathrm{~S}=2$ dengan skor $6, \mathrm{TS}=9$ dengan skor 18,STS = 9 dan yang menjawab pada nomor item negatif STS $=7$ dengan skor 28, TS $=10$ dengan skor $30, \mathrm{~S}=5$ dengan skor $10, \mathrm{SS}=5$, jadi jumlah data keseluruhan data mentah $=134$ dan data seharusnya $=216$, dapat dilihat pada tabel di bawah ini:

Tabel 5.

Rasa Marah

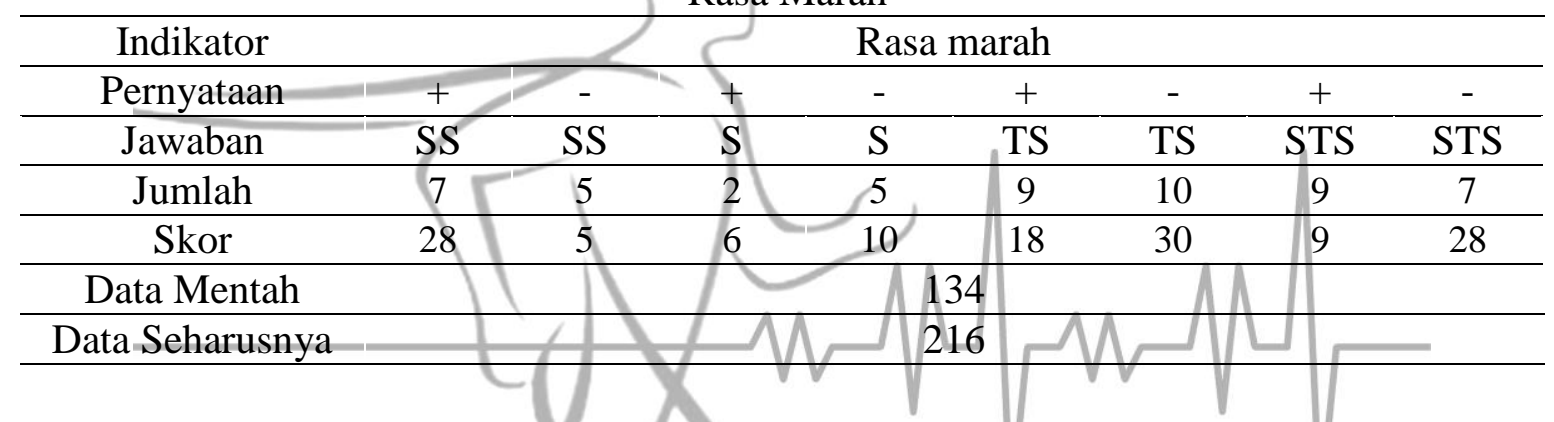

b. Indikator Emosi, diperoleh sebagai berikut: yang menjawab pada nomor item positif $\mathrm{SS}=10$ dengan skor $40, \mathrm{~S}=4$ dengan skor $12, \mathrm{TS}=7$ dengan skor $14, \mathrm{STS}$ = 6 dan yang menjawab pada nomor item negatif STS $=11$ dengan skor 44 , TS = 13 dengan skor $39, \mathrm{~S}=3$ dengan skor $6, \mathrm{SS}=0$ dengan skor 0 , jadi jumlah keseluruhan data mentah $=150$ dan data seharusnya 216 .

Tabel 6.

Emosi

\begin{tabular}{ccccccccc}
\hline Indikator & \multicolumn{8}{c}{ Emosi } \\
\hline Pernyataan & + & - & + & - & + & - & + & - \\
\hline Jawaban & SS & SS & S & S & TS & TS & STS & STS \\
\hline Jumlah & 10 & 0 & 4 & 3 & 7 & 13 & 6 & 11 \\
\hline Skor & 40 & 0 & 12 & 6 & 14 & 39 & 6 & 44 \\
\hline Data Mentah & & \multicolumn{7}{c}{150} \\
\hline Data Seharusnya & & \multicolumn{7}{c}{216} \\
\hline
\end{tabular}

c. Indikator Frustasi, diperoleh sebagai berikut: yang menjawab pada nomor item positif SS = 5 dengan skor $20, S=4$ dengan skor $12, \mathrm{TS}=14$ dengan skor 28 , STS $=4$ dan yang menjawab pada nomor item negatif STS $=8$ dengan skor $32, \mathrm{TS}=10$ dengan skor $30, \mathrm{~S}=5$ dengan skor $10, \mathrm{SS}=4$ dengan skor 4 , jadi jumlah keseluruhan data mentah $=140$ dan data seharusnya $=216$. 
Tabel 7 .

Frustasi

\begin{tabular}{|c|c|c|c|c|c|c|c|c|}
\hline Indikator & & & & & & & & \\
\hline Pernyataan & + & - & + & - & + & - & + & - \\
\hline Jawaban & SS & $\mathrm{SS}$ & $\mathrm{S}$ & $\mathrm{S}$ & $\mathrm{TS}$ & $\mathrm{TS}$ & STS & STS \\
\hline Jumlah & 5 & 4 & 4 & 5 & 14 & 10 & 4 & 8 \\
\hline Skor & 20 & 4 & 12 & 10 & 28 & 30 & 4 & 32 \\
\hline Data Mentah & \multicolumn{8}{|c|}{140} \\
\hline Data Seharusnya & \multicolumn{8}{|c|}{216} \\
\hline
\end{tabular}

d. Indikator Curiga,diperoleh data sebagai berikut: yang menjawab pada nomor item positif $\mathrm{SS}=10$ dengan skor $40, \mathrm{~S}=18$ dengan skor $54, \mathrm{TS}=0, \mathrm{STS}=1$ dengan skor 1 dan yang menjawab pada nomor item negatif STS = 14 dengan skor 56, $\mathrm{TS}=$ 14 dengan skor $42, S=3$ dengan skor $6, S S=0$, jadi jumlah keseluruhan data mentah $=199$ dan data seharusnya $=240$.

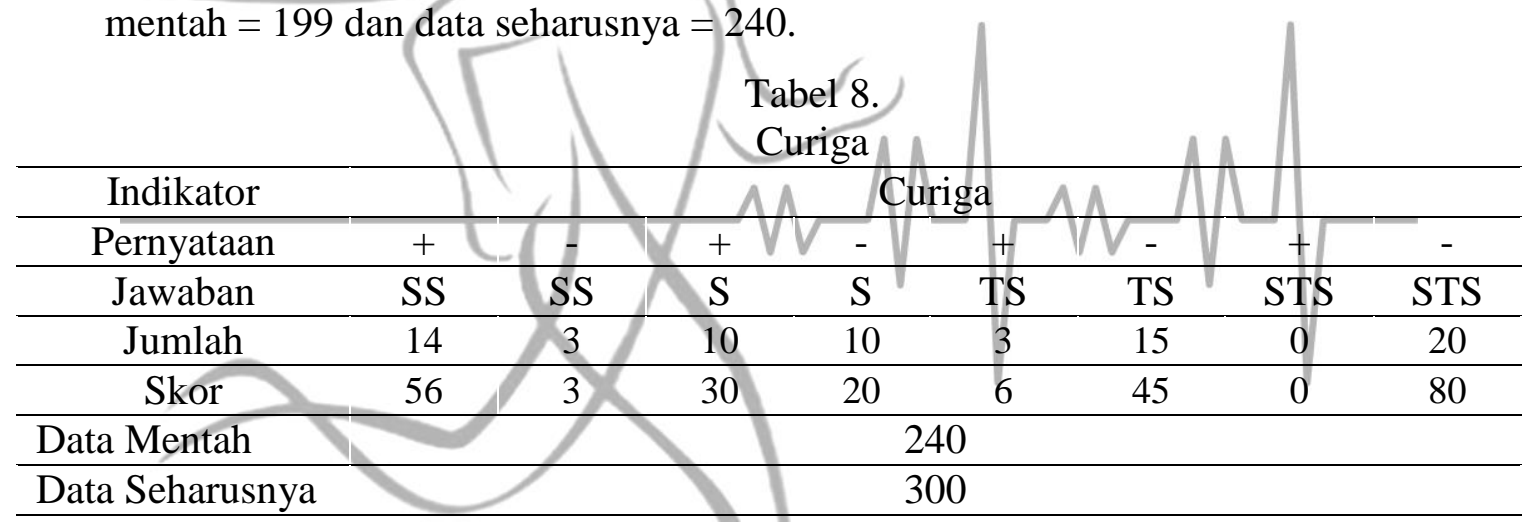

e. Indikator cemburu, diperoleh data sebagai berikut: yang menjawab pada nomor item positif $\mathrm{SS}=13$ dengan skor 52, $\mathrm{S}=11$ dengan skor 33, TS = 2 dengan skor 4, STS $=1$ dengan skor 1 , dan yang menjawab pada nomor item negatif, STS $=10$ dengan skor $40, \mathrm{TS}=8$ dengan skor $24, \mathrm{~S}=6$ dengan skor $12, \mathrm{SS}=4$ dengan skor 4 , jadi jumlah keseluruhan data mentah $=170$ dan data seharusnya $=220$.

Tabel 9.

Cemburu

\begin{tabular}{|c|c|c|c|c|c|c|c|c|}
\hline Indikator & & & & & & & & \\
\hline Pernyataan & + & - & + & - & + & - & + & - \\
\hline Jawaban & $\mathrm{SS}$ & $\mathrm{SS}$ & $\mathrm{S}$ & $\mathrm{S}$ & $\mathrm{TS}$ & $\mathrm{TS}$ & STS & STS \\
\hline Jumlah & 13 & 4 & 11 & 6 & 2 & 8 & 1 & 10 \\
\hline Skor & 52 & 4 & 33 & 12 & 4 & 24 & 1 & 40 \\
\hline Data Mentah & \multicolumn{8}{|c|}{170} \\
\hline Data Seharusnya & \multicolumn{8}{|c|}{220} \\
\hline
\end{tabular}


f. Indikator merasa diperlakukan tidak adil, diperoleh data sebagai berikut: yang menjawab pada nomor item positif $\mathrm{SS}=4$ dengan skor $16, \mathrm{~S}=5$ dengan skor 20 , TS $=7$ dengan skor 21, STS = 10 dengan skor 10, dan yang menjawab pada nomor item negatif STS = 12 dengan skor 40, TS = 7 dengan 21, S = 6 dengan skor 12, $\mathrm{SS}=4$ dengan skor 4 , jadi jumlah keseluruhan data mentah $=139$ dan data seharusnya $=218$

Tabel 10.

Merasa Diperlakukan Tidak Adil

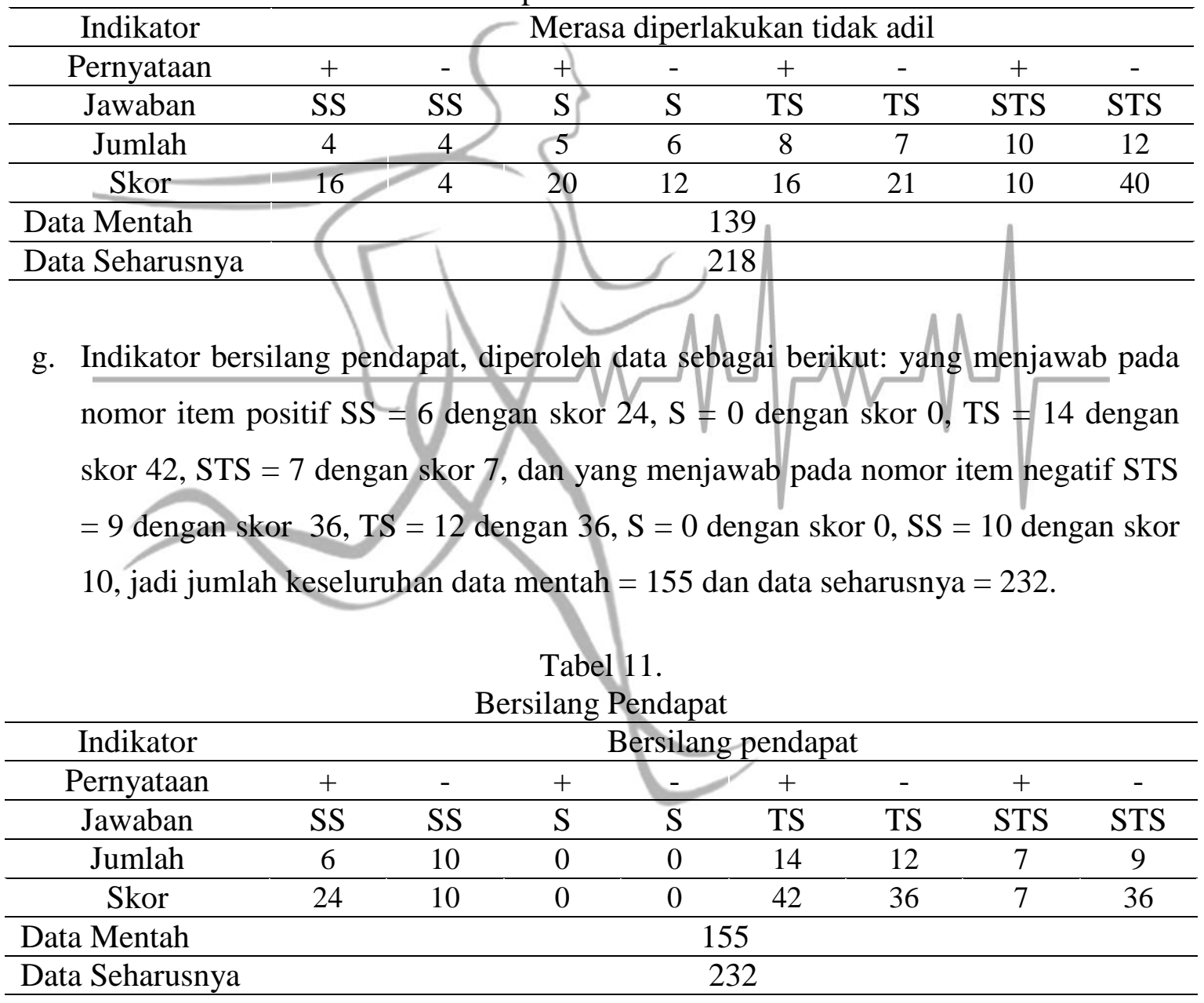

h. Indikator membentak, diperoleh data sebagai berikut: yang menjawab pada nomor item positif $\mathrm{SS}=17$ dengan skor $68, \mathrm{~S}=11$ dengan skor 33, TS = 1 dengan skor 2, $\mathrm{STS}=0$ dengan skor 0 , dan yang menjawab pada nomor item negatif STS $=5$ dengan skor $20, \mathrm{TS}=6$ dengan $18, \mathrm{~S}=12$ dengan skor $24, \mathrm{SS}=5$ dengan skor 5 , jadi jumlah keseluruhan data mentah $=170$ dan data seharusnya $=228$. 
Tabel 12 .

Membentak

\begin{tabular}{|c|c|c|c|c|c|c|c|c|}
\hline Indikator & & & & $\mathrm{Me}$ & atak & & & \\
\hline Pernyataan & + & - & + & - & + & - & + & - \\
\hline Jawaban & $\mathrm{SS}$ & SS & $S$ & $\mathrm{~S}$ & TS & TS & STS & STS \\
\hline Jumlah & 17 & 5 & 11 & 12 & 1 & 6 & 0 & 5 \\
\hline Skor & 68 & 5 & 33 & 24 & 2 & 18 & 0 & 20 \\
\hline Data Mentah & \multicolumn{8}{|c|}{170} \\
\hline Data Seharusnya & \multicolumn{8}{|c|}{228} \\
\hline
\end{tabular}

i. Indikator berdebat, diperoleh data sebagai berikut: yang menjawab pada nomor item positif $\mathrm{SS}=17$ dengan skor $68, \mathrm{~S}=11$ dengan skor 33, $\mathrm{TS}=1$ dengan skor 2, $\mathrm{STS}=0$ dengan skor 0 , dan yang menjawab pada nomor item negatif STS $=16$ dengan skor $64, \mathrm{TS}=21$ dengan $63, \mathrm{~S}=7$ dengan skor $14, \mathrm{SS}=1$ dengan skor 1 , jadi jumlah keseluruhan data mentah $=245$ dan data seharusnya $=296$.

Tabel13.

Berdebat

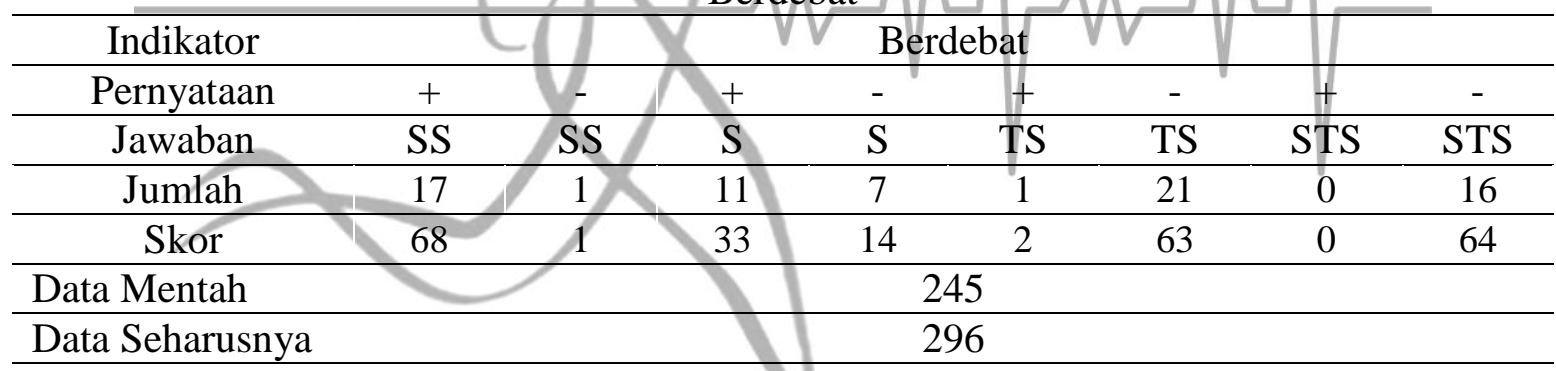

j. Indikator mengancam, diperoleh data sebagai berikut: yang menjawab pada nomor item positif SS = 10 dengan skor 40, S = 18 dengan skor 54 , TS = 0 dengan skor 0 , STS $=1$ dengan skor 1 , dan yang menjawab pada nomor item negatif STS $=14$ dengan skor $56, \mathrm{TS}=14$ dengan $42, \mathrm{~S}=3$ dengan skor $6, \mathrm{SS}=0$ dengan skor 0 , jadi jumlah keseluruhan data mentah $=199$ dan data seharusnya $=240$.

Tabel 14.

Mengancam

\begin{tabular}{|c|c|c|c|c|c|c|c|c|}
\hline Indikator & & & & $\mathrm{Me}$ & cam & & & \\
\hline Pernyataan & + & - & + & - & + & - & + & - \\
\hline Jawaban & SS & SS & $S$ & $S$ & $\mathrm{TS}$ & TS & STS & STS \\
\hline Jumlah & 10 & 0 & 18 & 3 & 0 & 14 & 1 & 14 \\
\hline Skor & 40 & 0 & 54 & 6 & 0 & 42 & 1 & 56 \\
\hline Data Mentah & \multicolumn{8}{|c|}{199} \\
\hline Data Seharusnya & \multicolumn{8}{|c|}{240} \\
\hline
\end{tabular}


Berdasarkan hasil analisa di atas dapat disimpulkan bahwa tingkat agresivitas atlet pencak silat sumatera utara mengikuti pekan olahraga wilayah ix di bangka belitung 2015 adalah kategori baik, dengan rekapitulasi data sebagai berikut:

Tabel 15.

Persentase Dan Rekapitulasi Data Setiap Indikator

\begin{tabular}{|c|c|c|c|c|c|}
\hline $\mathrm{NO}$ & Indikator & Mentah & Seharusnya & Persentase & Kategori \\
\hline 1 & Rasa Marah & 134 & 216 & $62.03 \%$ & Baik \\
\hline 2 & Emosi & 150 & 216 & $69.44 \%$ & Baik \\
\hline 3 & Frustasi & 140 & 216 & $64.81 \%$ & Baik \\
\hline 4 & Curiga & 240 & 300 & $80 \%$ & Baik Sekali \\
\hline 5 & Cemburu & 170 & 220 & $77.27 \%$ & Baik \\
\hline 6 & $\begin{array}{l}\text { Merasa diperlakukan } \\
\text { tidak adil }\end{array}$ & 139 & 218 & $63.76 \%$ & Baik \\
\hline 7 & Bersilang pendapat & 155 & 232 & $66.81 \%$ & Baik \\
\hline 8 & Membentak & 170 & 228 & $74.56 \%$ & Baik \\
\hline 9 & Berdebat & 245 & 296 & $82.77 \%$ & Baik Seali \\
\hline 10 & Mengancam & 199 & 240 & $82.91 \%$ & Baik Sekali \\
\hline & Jumlah & 1742 & 2382 & $73.13 \%$ & Baik \\
\hline
\end{tabular}

Setelah dilaksanakan penelitian yang diawali dari pengambilan data hingga pengolahan data penelitian terbukti bahwa tingkat agresivitas atlet pencak silat sumatera utara mengikuti pekan olahraga wilayah ix di bangka belitung 2015 dengan indikator rasa marah, emosi, frustasi, curiga, cemburu, merasa diperlakukan tidak adil, bersilang pendapat, membentak, berdebat dan mengancam menunjukkan bahwa tingkat agresivitas atlet pencak silat sumatera utara mengikuti pekan olahraga wilayah IX di bangka belitung 2015 kategori baik dengan nilai presentase $73.13 \%$.

Keberhasilan atlet dipengaruhi oleh sejumlah faktor yang saling mendukungantara faktor yang satu dengan lainnya.Faktor tersebut berasal dari dalam maupundari luar atlet itu sendiri yang meliputi faktor fisik, psikis, teknik, taktik, pelatih,sarana dan prasarana latihan, latihan, sosial, dan sebagainya.

Aspek psikis merupakan bagian dari pembinaan atlet untuk meraih prestasi tinggi sehingga perlu adanya kajian khusus mengenai hal tersebut yaitu psikologiolahraga. Psikologi olahraga merupakan bagian dari psikologi umum yang membantu mencetak atlet dari pemula menjadi juara atau memperlihatkan prestasinya, dan membantu atlet berbakat untuk mampu mengaktualisasikan bakatnya dalam prestasi puncak. 
Agresifitas dalam olahraga merupakan tenaga untuk bertanding yang muncul dari dalam atlet. Sebab jika dalam pertandingan olahraga tanpa (sedikit) agresifitas, atlet tidakmempunyai tenaga, kecepatan, dan ketegaran mental, namun sebaliknya jika agresifitas berlebihan akan mengakibatkan hukuman dan kerugian bagi atlet Anshel (1990: 150). Oleh karena itu agresifitas merupakan bagian dari permainan dalam olahraga.Artinya, agresifitas diperlukan dalam olahraga sepanjang masih dalarn batasbatas tidak merugikan diri sendiri dan lawan serta tidak melanggar peraturan permainan.

Secara garis besar jenis agresivitas dikelompokkan menjadi dua, yaitu: agresi rasa permusuhan (hostile aggression) dan agresi sebagai alat mencapai tujuan (instrumental aggression). Hostile aggression bertujuan untuk menyakiti orang lain, sedang seseorang melakukan instrumental aggression digunakan untuk mencapai kepuasan karenamotif- motif tertentu Morgan, (1984:289). Tujuan utama pada hostile aggression adalah menciderai dan menyakiti orang lain Cox (1994:289). Adapun cirinya adalah adanya rasa marah/dalam perilakunya, karena memang tujuan sesungguhnya adalah untuk untuk menciderai dan menyakiti lawan.Sebagai penguat atau mendorong atlet berperilaku agresif adalah agar lawan mengalami cidera atau sakit Straub (1980:179).

Sebaliknya pada instrumental aggression sebagai alat mencapai tujuan dengan usaha paksa atau upaya mempertahankan kekuasaan, dominasi, atau status sosial seseorang Berkowitz (1995:15).Tujuan dari instrumental aggression juga untuk menyakiti lawan, tetapi bentuk perilakunya tidak dengan rasa marah.Karena tujuan utamanya adalah untuk meraih kemengan dalam pertandingan. Dorongan atau motif atlet berperilaku agresif karena prestise, kemenangan,intimidasi, dan pembalasan Straub (1980: 179). Berdasarkan pengertian dan jenis agresifitas tersebut dapat disimpulkan bahwa agresifitas merupakan pola perilaku permusuhan yang dapat diwujudkan ke dalam bentuk penyerangan atau mempermainkan, dan menggoda orang lain. Sebagai pertanda dari perilaku agresif adalah adanya kebenarian dan semangat yang tinggi untuk mencapai satu tujuan.

Perilaku agresif bisa berupa verbal dan fisik, aktif, dan pasif, langsung. Perbedaan antara verbal dan fisik adalah antara menyakitisecara fisik dan menyerang dengan kata-kata: atau pasif membedakan antara tindakan yang terlihatdengan kegagalan dalam bertindak; perilaku agresif langsung berarti melakukan kontak 
langsung dengan korban yang diserang, sedangkan perilaku agresif tidak langsungdilakukan tanpa adanya kontak langsung dengan korban.

\section{KESIMPULAN}

Tingkat agresivitas atlet Pencak Silat Sumatera Utara mengikuti Pekan Olahraga Wilayah IX di Bangka Belitung 2015 dengan nilai persentase $73.13 \%$ termasuk dalam kategori baik.

\section{Daftar Pustaka}

Anna, Ayu Herawati. (2010). Hubungan Antara Kecerdasan Emosional Dengan Perilaku Agresif Siswa Kelas X Tm (Teknik Mesin) Smkn 2 Kota Bengkulu. UNIB

Andito Aryo, Amir Hassan. (2014). Faktor Penyebab Terjadinya Agresivitas Saat Bertanding Pada Atlet Sepakbola Pekan Olahraga Pelajar Daerah (Popda) Malang. Malang: UM

Bakhtiar, Dwi \& Andik Matulessy.(2012).Kecerdasan Emosi, Kecerdasan Spiritual dan Agresivitas pada Remaja.

Dimyati, Herwin, Tri Ani Hastuti.(2013). Karakteristik Psikologis Atlet di Pusat Pendidikan dan Latihan Pelajar (PPLP). Yogjakarta: UNY

Eki, Maulani.(2013). Hubungan Perilaku Agresif Dengan Tingkat Prestasi Taekwondo (Studi Deskriptif Pada Atlet Taekwondo Sdpn Sabang Bandung). Bandung: UPI

Husdarta. (2010). Psikologi Olahraga. Bandung :Alfabeta.

Juwarni. (2012). Pengaruh Playsta Tion Terhadap perilaku agresif siswa Dimitarbiyatussibyan Karangrayung Grobogan. UIN-SUKA

Lubis, Johansyah.(2014). Pencak Silat Edisi Kedua. Jakarta: PT Raja Grafindo Persada.

Nisfiannoor, M \& Eka Yulianti.(2005). Perbandingan Perilaku Agresif Antara Remaja Yang Berasal Dari Keluarga Bercerai Dengan Keluarga Utuh. Esa Unggul

Sukadiyanto. (2005). Agresifitas Dalam Olahraga. Yogjakarta: UNY 